\title{
Examination of the Challenges Facing Markets in Anambra State Nigeria
}

\author{
Mba, S.A ${ }^{1} \quad$ Obienusi, E.A ${ }^{2} \quad$ Obikwelu, M.C ${ }^{2 *}$ \\ 1. Department of Geography, NwaforOrizu College of Education, Nsugbe \\ 2. Department of Geography and Meteorology, NnamdiAzikiwe University, Awka
}

\begin{abstract}
This study examined the challenges facing markets in the rural areas of Anambra state, Nigeria. This study was carried out to enable one find out the major challenges facing rural markets as central places in Anambra state. The objectives of the study were to: ascertain the nearest - neighbor distance between the markets and to ascertain the major challenges facing the rural markets in the study area. Three hundred and ninety-nine (399) respondents were selected using stratified random sampling technique. The computation was done using t-test, Principal Component Analysis (PCA), Weighted Mean and Nearest-Neighbor Analysis. Analysis using the t-test indicated that the challenges facing the rural markets were significant while the Principal Component Analysis (PCA) indicated that the major challenge facing the market was the high cost of transportation of goods to the markets. The study concluded that the major challenges facing the rural markets limited the contributions of the rural markets to the socio-economic development of the state and therefore recommended that rural market linkages should be given adequate attention by the state and local government. This will be achieved by working in synergy with the various communities and market union organizations to create and maintain link and access roads in major rural markets.
\end{abstract}

Keywords: Rural areas, rural markets, central places, market linkages, market access

DOI: $10.7176 / \mathrm{JEES} / 9-12-06$

Publication date: December $31^{\text {st }} 2019$

\section{Introduction}

Market places are fundamental points of economic life and that traditional market system in Nigeria represents an articulation of spatial linkages which have been neglected in the post-independence development (Adelemo, 2009). Rural markets are sources of livelihood for the rural people and have played valuable roles in the development of the agrarian communities and neighboring towns in which they are located. (Asogwa, 2012). Beside rural commerce, rural markets also serve as centers for the exchange of ideas and civilization through social and political interaction. For these purposes, they generate high traffic flow and had opened-up channels of interaction with the outside world. (Datonjo, John, and Chikagbum, 2015).

Markets play essential roles in the economic development of a state and also help to increase the tax base of the state. Markets are also centers where the people have access to manufactured goods and surplus agricultural and non agricultural commodities.

The markets also help to establish rural-urban linkages which are crucial for rural development. The urban areas, rather than induce growth to outlying settlements, serve to milk them dry and eventually stagnate them economically (Uwadiegwu, Iyi and Ezenwaji, 2016).

Unfortunately, most of our rural markets have insufficient organized waste disposal, most of their roads are without drains, majority of the access roads within the markets are in poor conditions and there is generally no provision for water supply, while trading in the highway dominates the markets (Adekunle, 2015).

Against this background, the objective of the study, becomes vivid, that is to examine the challenges facing markets in Anambra state.

\section{Study Area}

This study was conducted in Orumba North Local Government Area of Anambra State. Orumba North Local Government Area has the geographical coordinates that lie between longitudes $6^{0} 7^{1} \mathrm{E}$ and $27^{0} 7^{1} \mathrm{E}$ and latitudes $5^{0} 40^{1} \mathrm{~N}$ and $6^{0} 48^{1} \mathrm{~N}$. It has an area of $297.00 \mathrm{~km}^{2}$ and a 2018 projected population of $204,597.25$; with a 2018 projected population density of $688.88 / \mathrm{km}^{2}$. 


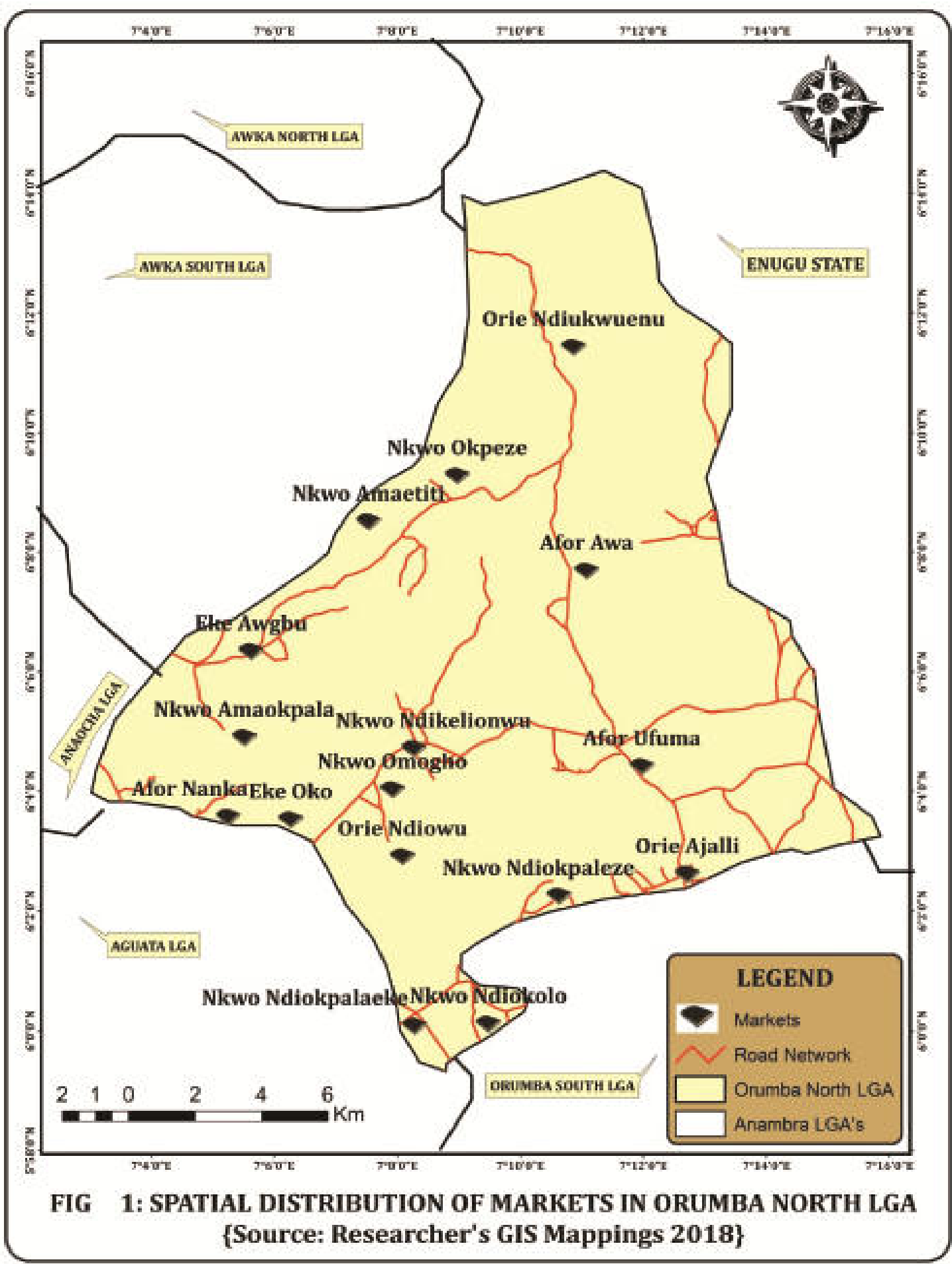

The area is located within the sub-tropical equatorial climate with an annualrainfall of about $200 \mathrm{~mm}$ and an average annual temperature of $27^{\circ} \mathrm{c}$ (Ofomata, 2000).

Orumba North falls within the rainforest zone of Nigeria. Although, annual rainfall is high, it is concentrated in one season, with about four months of dryness. It is made up of 16 communities and according to the 2006 census, the population of Orumba North is 172,773 with a male population of 84,996 and a female population of 87,777 (NPC, 2006). 


\section{Statement of the Problem}

The markets perform essential role as a center for the distribution of manufactured goods and locally produced agricultural and non-agricultural commodities. They are also centers for integrating communities into social and economic systems.

Unfortunately, the conditions of most of the markets in Anambra state are in a state of despair as a result of long standing institutional neglect; the access roads are poorly maintained while water and basic solid waste disposal services are lacking. The consequences being poor marketing network, wastage, underdeveloped agriculture and low income.

An impelling issue, therefore, is that there is need for a thorough understanding of the challenges facing markets so as to draw the attention of the state government to provide relevant logistic and policies, alleviate the challenges facing markets in the state.

\section{Conceptual Framework}

\subsection{Market}

A Market is a recognized medium that allows buyers and sellers of a specific good or service to interact in order to facilitate an exchange. It is also an event or occasion, usually held at regular interval, at which people meet for the purpose of buying and selling of merchandise. The term 'market' according to Holder and Ukwu (2009) is defined as an "authorized public concourse of buyers and sellers of commodities meeting at a place, more or less strictly limited or defined at a particular time". Thus, markets are invaluable socio-economic components of space.

Park(2001) noted that although the importance of markets to national development are unfortunately under estimated, they serve as focal points for communications and entertainment and points for rural evangelism.

Vagale (2003) classified markets into two different levels i.e local and regional. At the local level, commodities flow from the rural catchments to an urban node and vice versa, through daily market. At the regional level, rural markets are held at specific intervals to replenish stock of local markets in urban areas.

Anthonie (2003) asserted that market places are social centers. According to him, a market place is an avenue for courtship, visit, exchange of ideas and other social activities.

\section{Aim and Objectives}

The aim of this study is to examine the challenges facing markets in Anambra state. In order to achieve this aim, the following specific objectives are set:

1. to ascertain the nearest neighbor distance between the markets.

2. to ascertain the major challenges facing the markets.

\section{Methodology}

The author adopted the survey research design and the sample size was calculated using Taro Yamane (1967) sample size formula.

Three hundred and ninety-nine respondents were selected for the study. A structured questionnaire was constructed and administered to the respondents. The computation was done using t-test and Principle Component Analysis (PCA). The secondary data was collected from official records and the library; while several field study visits were made to obtain first hand information and to collect primary data from the 16 markets. 
Table 1: List of Communities, their markets and number of respondents selected.

\begin{tabular}{|l|l|l|l|}
\hline Name of Community & Name of Market & Population Size 2017(projected) & No. of Respondent Selected. \\
\hline Nanka & Afor Market & 38,780 & 77 \\
\hline Ufuma & Afor Market & 38,046 & 76 \\
\hline Awgbu & Eke Market & 32,135 & 64 \\
\hline Oko & Eke Market & 30,107 & 60 \\
\hline Ajalli & Orie Market & 13,200 & 26 \\
\hline Ndiowu & Orie Market & 12,441 & 25 \\
\hline Ndike & Nkwo Market & 7,698 & 15 \\
\hline Amaokpala & Afor Market & 5002 & 10 \\
\hline Awa & Afor Market & 4927 & 10 \\
\hline Omogho & Nkwo Market & 4826 & 10 \\
\hline Ndiukwuenu & Oye Market & 3106 & 6 \\
\hline Okpeze & Nkwo Market & 2683 & 5 \\
\hline Ndiokpalaeze & Nkwo Market & 2347 & 5 \\
\hline Amaetiti & Nkwo Market & 2092 & 4 \\
\hline Ndiokpalaeke & Nkwo Market & 1918 & 4 \\
\hline Ndiokolo & Nkwo Market & 885 & 2 \\
\hline & TOTAL & 200,193 & 399 \\
\hline
\end{tabular}

Source: Researchers fieldwork 2018.

\section{Discussion}

\subsection{Challenges Facing Markets in Anambra State}

Our field investigation revealed that although markets have existed and contributed to the development of the states, lip-service has been paid to physical infrastructural improvement and maintenance of most of the markets. Most markets are deficient of a proper drainage system, portable water storage facilities and so on (Angmor, 2012). In spite of thevarious agricultural development efforts by the state and national agencies which have brought about improve crop varieties and animal needs as well as better production techniques, the resultant increase in farm output has not necessarily translate to increase farm income for farmers in the study area. This is most due to lack of adequate market access and other market related factors in the area (Adejobi, Amaza and Ayoola, 2006).

Our findings revealed that none of the major 16 markets in the study area have portable water, electricity and health facilities, except Afor market Ufuma and Eke market Oko; whose water bore-hole facilities are not functional. The one at Afor market Ufuma was a private investor initiative while the ones at Eke market at Oko and Awgbu were government initiatives.

In terms of revenue collection, our investigation revealed that there was lack of adequate accountability and transparency, lack of adequate logistics for collection of revenue, weak institutional collaboration, lack of professional personnel and weak legal and reputational framework (Godfred, Dinye and Emmanuel, 2015).

This was due to the fact that various town union groups, including the local government officials were printing revenue receipts and collecting money from the traders.

In general, our investigation reveals that most of the markets have no sufficient organized waste disposal system in the markets; most of the access roads are without drains and in poor condition, while trading on the highway dominates the markets (Adekunle, 2015). 


\section{Average Nearest Neighbor Summary}

Nearest Neighbor Ratio: 1.505037

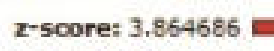

p-value: 0.000111
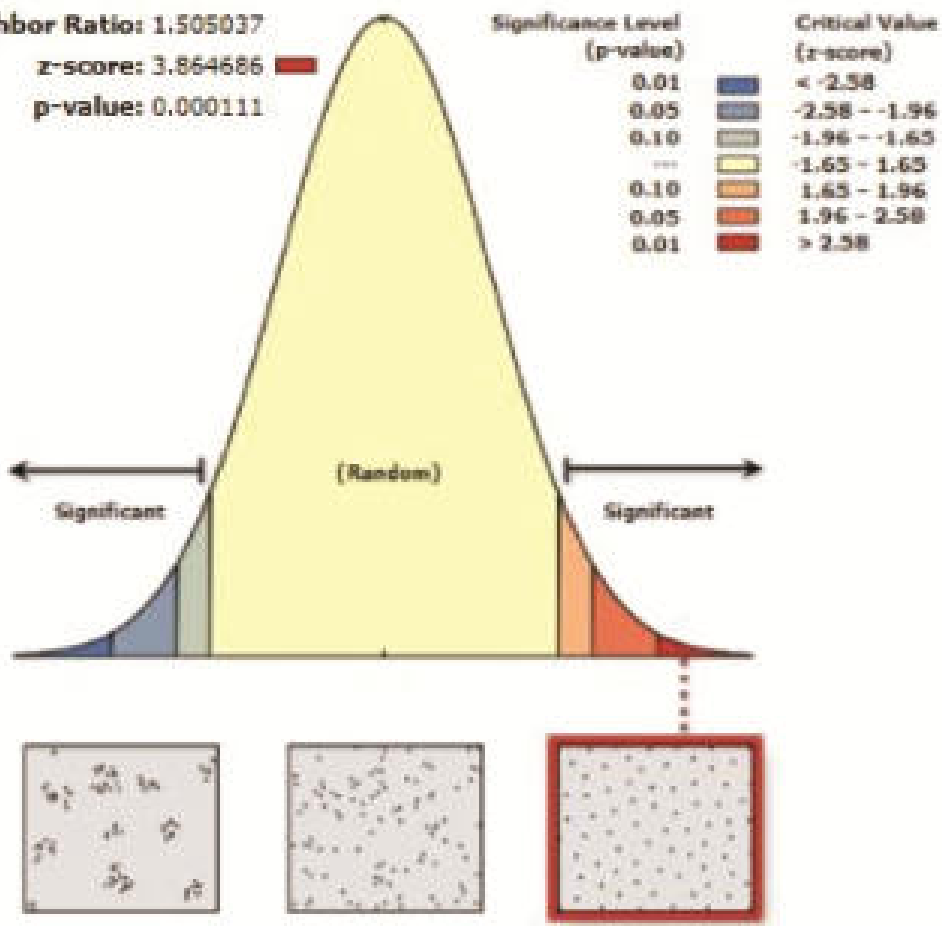

(Randum)

Significant

Clastered

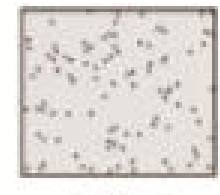

Randow

Given the $z$-score of 3.86468572213 , there is a less than $1 \%$ likelihood that this dispersed pattern could be the result of random chance.

\section{Average Nearest Neighbor Summary}

Observed Mean Distance: 2670.3885 Meters

Expected Mean Distance: 1774.3008 Meters

Nearest Neighbor Ratio: 1.505037

z-score: 3.864686

p-value: 0.000111

FIG. 2: AVERAGE NEAREST NEIGHBOUR ANALYSIS OF THE LOCATION OF RURAL MARKETS IN ORUMBA NORTH LGA

\{Researcher's GIS Analysis 2018\} 
Table 2: Challenges Facing Rural Markets in Orumba North

\begin{tabular}{|c|c|c|c|c|c|c|c|c|c|}
\hline \multirow[t]{2}{*}{ S/No } & \multirow[t]{2}{*}{ ITEM } & \multirow{2}{*}{\multicolumn{5}{|c|}{ RESPONSES }} & \multicolumn{2}{|c|}{ STATISTICS } & \multirow[t]{2}{*}{ Remark } \\
\hline & & & & & & & Mean & STD & \\
\hline 1. & Lack of Access roads in the market & 96 & 77 & 57 & 108 & 61 & 3.0977 & 1.4258 & Accepted \\
\hline 2. & Lack of potable water & 75 & 94 & 120 & 69 & 41 & 3.2331 & 1.2325 & Accepted \\
\hline 3. & Irregular Electricity supply & 64 & 93 & 121 & 101 & 20 & 3.2005 & 1.1363 & Accepted \\
\hline 4. & Lack of Adequate security of goods & 81 & 67 & 87 & 149 & 15 & 3.1253 & 1.2213 & Accepted \\
\hline 5. & Lack of suitable stalls & 112 & 54 & 191 & 33 & 9 & 3.5689 & 1.0536 & Accepted \\
\hline 6. & Multiple fee payments & 163 & 39 & 98 & 76 & 23 & 3.6090 & 1.3365 & Accepted \\
\hline 7. & Lack of ware house & 51 & 78 & 120 & 99 & 51 & 2.9474 & 1.2112 & Rejected \\
\hline 8. & Lack of toilet facilities & 94 & 131 & 74 & 81 & 19 & 3.5013 & 1.1901 & Accepted \\
\hline 9. & Lack of effective drainage system & 62 & 79 & 187 & 61 & 10 & 3.3058 & 0.9907 & Accepted \\
\hline 10. & Lack of bulk purchase of goods & 98 & 105 & 92 & 75 & 29 & 3.4211 & 1.2453 & Accepted \\
\hline 11. & $\begin{array}{l}\text { High cost of Transport of goods to } \\
\text { the market }\end{array}$ & 114 & 89 & 92 & 75 & 29 & 3.4612 & 1.2790 & Accepted \\
\hline 12. & $\begin{array}{l}\text { Lack of up-to-date market } \\
\text { information }\end{array}$ & 187 & 79 & 62 & 61 & 10 & 3.9323 & 1.2084 & Accepted \\
\hline 13. & $\begin{array}{l}\text { Lack of Health facilities in the } \\
\text { market. }\end{array}$ & 108 & 96 & 77 & 57 & 61 & 3.3333 & 1.4041 & Accepted \\
\hline 14. & $\begin{array}{l}\text { Lack of organized waste disposal } \\
\text { system }\end{array}$ & 101 & 121 & 102 & 55 & 20 & 3.5714 & 1.1536 & Accepted \\
\hline 15. & Lack of parking facilities & 46 & 92 & 99 & 117 & 45 & 2.9424 & 1.1984 & Rejected \\
\hline 16. & Lack of maintenance of stalls & 120 & 93 & 111 & 55 & 20 & 3.5965 & 1.1925 & Accepted \\
\hline
\end{tabular}

Source: Researchers fieldwork 2018.

Table 3: T-test for Challenges facing Rural Markets

One-Sample Statistics

\begin{tabular}{|l|r|r|r|r|}
\hline & $\mathrm{N}$ & Mean & Std. Deviation & \multicolumn{1}{c|}{ Std. Error Mean } \\
\hline Challenges facing Rural Markets & 16 & 3.365450 & .2684478 & .0671119 \\
\hline
\end{tabular}

One-Sample Test

\begin{tabular}{|c|c|c|c|c|c|c|}
\hline & \multicolumn{6}{|c|}{ Test Value $=3.0$} \\
\hline & \multirow[b]{2}{*}{$\mathrm{T}$} & \multirow[b]{2}{*}{ Df } & \multirow{2}{*}{$\begin{array}{l}\text { Sig. (2- } \\
\text { tailed) }\end{array}$} & \multirow{2}{*}{$\begin{array}{c}\text { Mean } \\
\text { Difference }\end{array}$} & \multicolumn{2}{|c|}{$\begin{array}{l}\text { 95\% Confidence Interval of the } \\
\text { Difference }\end{array}$} \\
\hline & & & & & Lower & Upper \\
\hline $\begin{array}{l}\text { Challenges facing } \\
\text { Markets }\end{array}$ & 5.445 & 15 & .000 & .3654500 & .222404 & .508496 \\
\hline
\end{tabular}

Hypothesis Three

Ho: The challenges facing the rural markets are not significant.

$\mathbf{H}_{1}$ : The challenges facing the rural markets are significant.

Statistical tool: One Sample t -test

Reason for choice of tool: One level of observation was compared to a value.

Decision Rule: Accept the null hypothesis if the $\mathrm{p}-$ value is greater than or equal to 0.05 , otherwise, reject the null hypothesis.

Decision, Conclusion and Reason: From the table, we see that mean value is 3.36545 , greater than 3.0 and the mean difference is 0.36545 with a $\mathrm{p}$ - value of 0.000 (less than 0.05 ). Thus, the null hypothesis is rejected.By this we can say that the challenges facing the rural markets are significant; that is the various challenges observed are significant. 
Table 4: Total Variance Explained

\begin{tabular}{|c|c|c|c|c|c|c|}
\hline \multirow[b]{2}{*}{ Component } & \multicolumn{3}{|c|}{ Initial Eigenvalues } & \multicolumn{3}{|c|}{ Extraction Sums of Squared Loadings } \\
\hline & Total & $\%$ of Variance & Cumulative $\%$ & Total & $\%$ of Variance & Cumulative \% \\
\hline 1 & 14.068 & 87.925 & 87.925 & 14.068 & 87.925 & 87.925 \\
\hline 2 & .968 & 6.052 & 93.977 & & & \\
\hline 3 & .352 & 2.199 & 96.176 & & & \\
\hline 4 & .182 & 1.137 & 97.313 & & & \\
\hline 5 & .085 & .531 & 97.844 & & & \\
\hline 6 & .077 & .480 & 98.324 & & & \\
\hline 7 & .054 & .339 & 98.663 & & & \\
\hline 8 & .053 & .332 & 98.995 & & & \\
\hline 9 & .038 & .238 & 99.233 & & & \\
\hline 10 & .031 & .195 & 99.428 & & & \\
\hline 11 & .029 & .179 & 99.606 & & & \\
\hline 12 & .019 & .120 & 99.726 & & & \\
\hline 13 & .017 & .104 & 99.830 & & & \\
\hline 14 & .012 & .078 & 99.908 & & & \\
\hline 15 & .009 & .055 & 99.963 & & & \\
\hline 16 & .006 & .037 & 100.000 & & & \\
\hline
\end{tabular}

Extraction Method: Principal Component Analysis.

Only one component was extracted as can be seen from this table and that component extracted about $87.925 \%$ of total variance.

Table 5: Component Matrix ${ }^{\mathrm{a}}$

\begin{tabular}{|l|r|}
\hline & Component \\
\cline { 2 - 2 } & 1 \\
\hline 9. The markets serve as centre for diffusion of innovation & .985 \\
14. The markets integrate the primary producers into regional/national economy & .975 \\
16. Basic goods and services are always available at the markets & .974 \\
2. The markets protect bulk goods from climate elements & .973 \\
11. The markets sustain the rural areas economically & .971 \\
4. The markets help to increase rural income & .969 \\
13. The markets link the rural economy to urban economy & .964 \\
3. The markets serve as communication centers & .964 \\
15. The markets serve as centers for employment & .963 \\
10. The markets serve as centers for distribution of manufactured goods & .961 \\
8. The markets serve as social centers & .959 \\
1. The market is an avenue for aggravating rural surplus & .930 \\
5. The markets serve as centers for political decision making & .924 \\
12. The markets serve as centers to meet relations & .917 \\
7. The markets help to reduce rural - urban migration & .909 \\
6. The markets serve as centers for traditional religious functions & .595 \\
\hline
\end{tabular}

Extraction Method: Principal Component Analysis.

a. 1 components extracted.

The PCA for the effectiveness of the rural markets can be viewed as being majorly as so; that is, the major role the rural markets render in the area is that they (the rural markets) serve as centre for diffusion of innovations. 


\section{Findings}

Based on the objectives, the research discovered that;

1. The major challenge facing the markets is high cost of transportation of goods to the markets.

2. Using the nearest-neighbor analysis, it was discovered that the mean nearest neighbor distance for the study area is 2670.39 meters (fig 2).This depicts efficient locational configuration, since people only have to travel for that distance to get to the nearest market. However, the efficiency of the locational configuration is often constrained by socio-economic distance among other difficulties that limits market integration.

3. Most of the markets are in a deplorable state: no regular source of water supply, no electricity and no efficient solid waste disposal system.

\section{Recommendations}

From the findings, the following recommendations are made:

1. Market linkages should be given adequate attention by the state and local government councils. This should be done by them working in synergy with the various towns and markets union organizations to create and maintain link and access roads in the major markets.

2. The local government authorities should educate the traders and participate with them in the regular environmental sanitation in the various major markets in the state.

3. Spirited efforts should be made by the various governmental agencies to establish basic facilities like potable water, access roads and solid waste disposal system .This should be managed by the host communities.

\section{Conclusion}

This study has firmly established that there have been numerous challenges facing markets development in Anambra state, and these have limited the contribution of markets to the socio-economic development of the state. The government agencies should be sincere enough in their dealings involving the people: the cases were non-functional bore-holes were sunk and commissioned is very regrettable. A case in point is at Eke Oko and Eke Awgbu Markets.

\section{References}

Adejobi, A; Amaza, P; \&Ayoola, G. (2006).” Enhancing the Access of Rural Households to Output Markets for Increased Farm Incomes." Poster Paper Presented at the International Association of Agricultural Economists Conference, Gold Coast, Australia, August 12-18, 2006.

Adekunle, F. (2015). Management of Traditional Markets in Ibadan, Nigeria. A focus on Oja'ba and Oje Markets Balogun. Retrieved from http:/ww.regionalstudies.org/uploads/Balogun Femi Adekunle.pdf.

Adelemo, A.I (2009). Small Urban Centers in Nigeria's Development Strategy; The Role of Rural Market Centers, Small Urban Centers in Rural Development in Africa. African studies, 1. Pp 128-130.

Angmor, E.N (2012). The Role of Transportation Service in the Development of Traditional Markets: A Case Study of Asesewa and Agormanya Traditional Markets in the Eastern Region, Ghana. A M.Sc. Thesis submitted to the school of Graduate Studies, Kwame Nkrumah University of Science and Technology.

Anthonie, Q.O.B. (2003). The Supply and Distribution of Yams in Ibadan Market.The Nigeria Journal of Economic and Social Studies; 9(1): 33-49.

Asogwa, B.C. (2012). Marketing of Agricultural Produce among Rural Farm Households in Nigeria: The Case of Sorghum Marketing in Benue State. International Journal of Business and Social Sciences vol.3 (13), July 2012 p 269.

Datonjo, K; John, D. \&Chikaghum, C. (2015). Development of Rural Periodic Market Centers: An Effective Strategy for Rural Development in River State, Nigeria. Developing Countries Studies www.iiste.org ISSN 2224-607X (paper) ISSN 2225-0565 (Online) Vol.5 (12), 2015.

Godfred, A., Dinye, R. D. \& Emmanuel, O. (2015). The Contribution of Periodic Markets to Internally Generated Fund (IGF) of Ejisu-Juaben Municipal Assembly. Journal of Studies in Social Sciences.vol.11.no 1, 201 ISSN 2201-4624.

Holder, B.W. \&Ukwu, U. (2009). Markets in West Africa. Ibadan University Press. International NGO Journal vol. 4(4) p. 175

National Population Commission (2006). Abuja: Federal Government Press, Moore Road, Apapa.

Ofomata,G.E.K,(2000). 'Erosion in Rain Forest Zone of Nigeria'. A paper Presented at the Annual Conference of Nigerian Geographical Association, University of Nigeria,Nsukka, March, 2000.

Park, K. (2001). "Emerging Trends in Agro Processing Sector”. Indian Journal of Agricultural Economics. JanMarch. Pp 51-54Taro Y. (1967). University Statistics: An Introductory Analysis, Second Edition, New York: Harper and Row. 
Uwadiegwu, B.O., Iyi, E.A; \&Ezenwaji, E.E. (2016). "Serviceability Capacity of Nigerian Cities" in Tropical Built. Environment Journal (TBEJ). Vol.1 (5), August, 2016. ISSN: 2276-6014 p 8-21.

Vagale, D. (2003). "Micro finance and Rural Non-farm Sector: Some NGO Experiences", in RohincNayyer and Alkak, N. Sharma (eds), Rural transformation in India: The role of non-farm sector, New Delhi: Manohar Publishers. Pp 429-446. 